\title{
Erratum to: Exploring the relationship between adolescents' reading skills, reading motivation and reading habits
}

\author{
Sarah P. McGeown • Lynne G. Duncan • \\ Yvonne M. Griffiths • Sue E. Stothard
}

Published online: 23 January 2015

(C) Springer Science+Business Media Dordrecht 2015

\section{Erratum to: Read Writ \\ DOI 10.1007/s11145-014-9537-9}

The title in the original article has been published incorrectly. The correct version is given in this erratum.

The online version of the original article can be found under doi:10.1007/s11145-014-9537-9.

S. P. McGeown ( $\square)$

School of Education, University of Edinburgh, Edinburgh, UK

e-mail: s.mcgeown@ed.ac.uk

L. G. Duncan

School of Psychology, University of Dundee, Dundee, UK

Y. M. Griffiths

Institute of Education, University of London, London, UK

S. E. Stothard

Centre for Evaluation and Monitoring, University of Durham, Durham, UK 